JOALL (JOURNAL OF APPLIEI) LINGUIS'IICS ANI) LITIERA'TURE)

\title{
THE YOUNG LEARNERS' PERCEPTION TOWARDS ENGLISH INSTRUCTIONAL PRACTICES USING VIRTUAL PLATFORMS
}

\author{
1 Purwanti Taman (D), 2Sukma Septian Nasution (D), ${ }^{3}$ Tommy Hastomo (D), \\ ${ }^{4}$ Nur Najibah Sukmawati (D), ${ }^{5}$ Laksmy Ady Kusumoriny \\ 1,2,4,5 Universitas Pamulang; ${ }^{3 S T K I P ~ P G R I ~ B a n d a r ~ L a m p u n g ~}$
}

Corresponding email: dosen02032@unpam.ac.id

\begin{abstract}
The popularity of virtual-learning platforms as an alternative for instructional practices during the pandemic is rocketing yet students' perceptions to the implementation are not optimally gauged especially to young learners. This study explores the students' perception towards learning English using two popular virtual platforms during Covid-19 pandemic. This is a case study involving 30 students in their third-year study at a private primary-school primary school in Tangerang City, Banten. Interviewing and observing all students respectively were conducted to obtain the data needed. Using descriptive analysis, it was found that the students showed negative perceptions towards the onlinebased learning process. Not only the media but also the whole learning process was negatively impacted. This is a voice that highlights the issue of recent education is facing. Further studies are therefore suggested to delve into effective and feasible solutions to eradicate the negative perception because the best time to return to classroom-situated instructions remains arguable for no-exact time.
\end{abstract}

Keywords: Perception, Virtual Platforms, Young Learners

\section{INTRODUCTION}

The education sector is the area with the most significant impact due to the Covid-19 epidemic, which has existed in almost all countries in the world. The last two years were the most challenging for students because they could not hold face-to-face lectures. Consequently, students from elementary schools to tertiary institutions have implemented distance learning since the beginning of April 2020. All schools and universities in Indonesia must postpone all practices of learning activities to mitigate viruses transmitted in schools based on the Circular of the Ministry of Education and Culture Number 3 of 2020 
Purwanti Taman, Sukma Septian Nasution, Tommy Hastomo, Nur Najibah Sukmawati, Laksmy Ady Kusumoriny

from the Ministry of Education and Culture (Nasution et al., 2020). So that one alternative to maintaining learning practices is virtual learning.

Few years ago, online learning is considered uncommon for most people in Indonesia. Most of schools relied on classroom-situated instructional practices where teachers and students meet in person, make direct interaction, share information, and so on without any boundary. However, the pandemic compels an absolute change that the use of online learning is massive and teacher-student interaction is different (Onyema, Ogechukwu \& Anthonia, 2019).

Studies about the implementation of online-learning during Covid-19 outbreak are flowering with various concerns like students' perception (Nasution \& Ahmad, 2020; Rakhmanina, et. al, 2020; Agung, Sukartini, \& Op, 2020; Sudewi, 2020), students' responses (Wargadinata, Maimunah, Rofiq, 2020; Astuti \& Indrani, 2020; Krishnapatria, 2020), teacher's perceptions (Rahayu \& Wirza, 2020), teacher strategies in using virtual platforms (Lestiyanawati, 2020), online-learning satisfaction (Basith, Rosmaiyadi, Triani, \& Fitri, 2020), comparing its implementation between in Indonesia and in Malaysia (Saputri, Khan \& Kafi, 2020). These studies are academic responses to the rapid changes of instructional practices in Indonesia seen from either student perspectives. When particularly discussing student perspectives, the concerns can vary to what year the students are, whether they have enough exposure to technology-based instructions, and whether they are independent users of technology-based learning.

The effect of Covid-19 pandemic is faced by all level students including young ages. Like other students, young learners need to adapt instructional practices via online. The challenges appear when they are considered having little exposure to technology than high school students in comparison. Multimodal learning provided in virtual platforms may confuse them in comprehending materials. This is a basis of conducting this study that young learners' perception towards virtual learning should not be neglected. Indeed, they need attentive space to voice out their perceptions to learning using virtual platforms.

Young learners need scaffolding and guidance because they are not ready to be independent (Sukmawati, 2018). Ideal implementation of instructional practices are suggested by some experts as follows: (1) mixing first language and English to converse with other children (Elliot, 2004); (2) the use of simple questions (Santosa, 2014); ((3) making use of familiar songs, rhymes, and poems (Wilcox in Fauziati, 2010); (4) using first language with peers who speak the same first language to clarify instructions; (5) responding to basic question words like who, what, where, and when; (6) knowing and following directionality in text (York in Coulmas, 2005); (7) communicating observations after teacher modeling (e.g., Our tower is 10 blocks high). These 
indicators are feasible to be implemented offline, but the constraint to do so currently makes teachers need to adapt the practices in virtual platforms. The adaptation potentially deviates from the afore-mentioned ideal practices. The deviation may cause different perception for young learners. Students who are not ready may end frustrating or find the classroom not interesting. Therefore, it is significant to have their inputs to be insightful reflection for teachers for young learners to prepare and perform their best in teaching children using virtual platforms in this pandemic situation.

Perception refers to the process of receiving stimuli in objects, qualities, relationships between symptoms and events, until the stimuli are realized and understood by individuals (Irwanto in Hammi, 2017). Perception is not just a sense but also an interpretation of experience, after the sensing process. The interpretation is insightful when it is used for certain purposes. Towards virtual-learning practices, students' perceptions are an expression of responses after having online learning experience. The perception might appear differently from every student due to different interpretations of each individual.

The instructional implementation using virtual platforms is also used by young learners in a private elementary school in Tangerang. A class of their third-grade is obliged to having Zoom application and Google Classroom as platforms to conduct instructional practices. Zoom Meeting application is a video-based learning media that was inaugurated in 2011. This application is widely used for learning activities and other activities that connect many people remotely because it can help communicate directly with anyone through video, as well as have the feature to do presentations in front of people by online (Nasution, Tryana, Sagimin, \& Ginting, 2020). Therefore, this application is considered very appropriate to use in the online learning process. The Zoom Meeting application can be used for free with a 45-minute time limit and no time limit when using an account for a fee.

According to Joseph (2020), Zoom is an online audio and web conferencing platform. People use it to make phone calls or to participate in video conference meetings. It was founded in 2011 by Eric Yuan, a former Cisco executive. Cisco offered the WebEx web conferencing platform, which remains a competitor in the conferencing space today. Yuan's competitor, Zoom, evolved quickly; the service launched in 2013 and had a million users by the end of the year. By 2017, the company had a billion-dollar valuation. It became a publicly-traded company in 2019 and has grown into one of the biggest video conferencing solutions in use today.

On the other hand, Google Classroom application inaugurated in 2014 by Google can be used as a medium to help with the learning process. The Google Classroom app helps teachers create and organize classroom assignments quickly and easily, providing students with feedback directly 
Purwanti Taman, Sukma Septian Nasution, Tommy Hastomo, Nur Najibah Sukmawati, Laksmy Ady Kusumoriny

and efficiently, and making communication with students indefinitely by space and time. Google Classroom is currently considered the best platform that can be used in online learning and is able to improve the quality and effectiveness of online learning (Latif, 2016).

Google Classrooms and Google Meet are frequently used as teaching media alternatives during this pandemic. Therefore, for some people who have supporting facilities, online learning activities are considered as the best alternative to the current pandemic conditions, because it can be used from anywhere and anytime in accordance with the agreement that has been determined between teachers and students (Adijaya and Santoso, 2018).

However, some of the people with inadequate facilities and support such as technology and internet connection have the assumption and views that online learning is burdensome (Nasution, et al. 2020). The difficulty of online learning is particularly experienced by elementary students because they naturally still need direct guidance from teachers and parents (Sukmawati, 2018). Most of them are dependent learners and therefore have different ideas of using the platforms in learning. Further, learning English using the platforms may also cause specifically different challenges and opportunities. It is significant to explore their perspectives towards learning English using the platforms to obtain insightful information from them to reflect future instructional practices.

\section{METHODS}

This is a qualitative descriptive study aiming at exploring the students' perceptions of online learning by using Zoom and Google Classroom. A qualitative approach is a research method used to naturally examine objects' conditions where researchers act as a critical instrument (Sugiyono, 2016). Descriptive research is a study that systematically describes the facts and characteristics of the research population to collect detailed information and determine what the research subjects are doing in the face of naturally researchedconditions without engineering (Sukmadinata, 2012).

\section{Instruments}

Two instruments were deployed to obtain the data. They are semi-structured interview and observation sheet. Moleong (2016) stated that the interview is a conversation conducted to know a theme. The conversation undertaken by two parties, the interviewer who asks questions and the source as the party, provides information on the interviewer's question. In this study, theprocess of interviewing was conducted by the writer to grade 3 students at a private elementary school in Tangerang. The number of grade 3 students who were respondents to this study was 30 people. This study practiced a semi- 
structured interview to obtain deep and natural information from the young learners. The interview guideline is presented in Table 1.

Table 1. The Semi-Structure Interview

\begin{tabular}{c|c}
$\begin{array}{c}\text { Aspect of } \\
\text { perception }\end{array}$ & \multicolumn{1}{c}{ Questions } \\
\hline $\begin{array}{c}\text { Cognitive } \\
\text { (knowledge) }\end{array}$ & $\begin{array}{l}\text { 1. Is learning English by online more difficult than face-to- } \\
\text { face? }\end{array}$ \\
& $\begin{array}{l}\text { 2. Do you know Zoom and Google Classroom apps? } \\
\text { 3. Does the teacher clearly explain the English language } \\
\text { material during online learning? } \\
\text { 4. What are the problems you getwhen online learning? } \\
\text { 5. Which apps are the easiest to use in online learning? }\end{array}$ \\
\hline Affective & $\begin{array}{l}\text { 6. Is it fun to online learning from home? } \\
\text { 7. Which apps are the most funto use during learning? } \\
\text { 8. Are you tired of doing online learning by using the } \\
\text { Zoomapp and Google Classroom? }\end{array}$ \\
\hline $\begin{array}{c}\text { Conative } \\
\text { (Psychomotor) }\end{array}$ & $\begin{array}{l}\text { 9. Do you feel motivated to learn while online learning by } \\
\text { using the Zoom app and Google Classroom? } \\
\text { 10. Do you always follow online learning on time by using } \\
\text { Zoom and Google Classroom? }\end{array}$ \\
\hline
\end{tabular}

To validate the finding from interview, the data were cross-checked by observation. Observation is a data collection technique conducted through observations accompanied by a recording of research objects' circumstances or behaviour (Sugiyono, 2016). Observations were used in this study to find out the online learning process using the Zoom and Google Classroom applications during the Covid-19 Pandemic at SD Islam Panji Nusantara. The data obtained in the form of observations made by the writer from the results of communicating and interacting with the study's subjects and objects. Therefore, the writer gets the opportunity to know the online learning process that will be the material for the research report's discussion process. The following observation guidelines in this study are presented in Table 3.3.2 shown in Table 2. 
Purwanti Taman, Sukma Septian Nasution, Tommy Hastomo, Nur Najibah Sukmawati, Laksmy Ady Kusumoriny

Table 2. The Observation Sheet

\begin{tabular}{c|ll}
\hline Stages & \multicolumn{1}{c}{ Indicator of Observation } \\
\hline Opening & $\begin{array}{l}\text { 1. The students' activities before starting the meeting. } \\
\text { 2. The students' activities while teachers are opening } \\
\text { the class. }\end{array}$ \\
& $\begin{array}{c}\text { 3. The students' responses to every question given by } \\
\text { the teachers. }\end{array}$ \\
\hline Core Activities & $\begin{array}{l}\text { 4. The students' participation during instructional } \\
\text { practices. } \\
\text { Closing }\end{array}$ & $\begin{array}{l}\text { The students' engagement to the materials presented } \\
\text { by the teachers. }\end{array}$ \\
& $\begin{array}{l}\text { 7. Interaction between teacher and students. } \\
\text { 8. Students' request for personal feedback }\end{array}$
\end{tabular}

The observation result is converted into scores ranged from 3 which means very good, 2 which means good, and 1 which means poor. This observation was conducted by joining the class passively without being noticed by the students.

\section{FINDINGS}

This study is qualitative research to know the students' perception of English learning by using zoom and Google Classroom during the Covid19 pandemic. The following is presented in Table 3 on the description of the students who were respondents in this study based on gender.

Table 3. Description of student characteristics by gender

\begin{tabular}{lcc} 
Gender & Frequency & Percentage (\%) \\
\hline a. Boys & 20 & 66,7 \\
b. Girls & 10 & 33,3 \\
\hline Total & $\mathbf{3 0}$ & $\mathbf{1 0 0 , 0}$ \\
\hline
\end{tabular}

Table 3 shows that most of the grade 3 students who were respondents in this study were boys as many as 20 people $(66.7 \%)$, and the remaining were girls of 10 students. The third-grade students are at the age of 9 and 10 years old. The interview guidelines used in this study have been adapted to the aspects of perception described by Walgito (2010), namely the aspects of cognitive (knowledge), aspects of affective and conative (psychomotor). Furthermore, observation sheets are used to find out the online learning process using the Zoom and Google Classroom during the Covid-19 Pandemic conducted by the teacher. The interview and observation process 
were conducted online or remotely, from 22 to 23 February 2021 during English learning hours, using the Zoom Meeting app. The writer performs all data retrieval processes as the main instrument in the study.

The first day of observation process was conducted on February 22, 2021 from 10:00 a.m. to 11:10 a.m. The observations were made by observing the English learning process using Zoom and Google Classroom, from the preparation process, implementation to learning evaluation. The learning process is done using Zoom application, then the process of assignment and collecting assignments through Google Classroom platform. During the learning process, the teacher prepares all the necessary online learning facilities, especially the internet connection. The learning process begins with a prayer, and then the teacher starts to explain the names of animals that are often found in the home environment in English. The teacher teaches how to read and to write the animals' names well and asks each student to repeat the pronunciations. The teacher then gives some practice questions to write down thenames of plants that are often found around the house, and the teacher asks students to submit the assignment through Google classroom. Furthermore, teachers give conclusions about the learning process and ask students to maintain health and keep studying diligently with family at home during the Covid-19 Pandemic. Moreover, the learning process ends with prayers and greetings.

On the second day of the observation on February 23, 2021 from 09.00 to $10.15 \mathrm{WIB}$, the writer conducted interviews with ten students selected based on English scores, namely seven students with good English scores and three students with poor English scores. The interview process was conducted on the same day achieved through the Zoom Meeting application. The interview process was conducted directly by the writer and students to get information about students' perception of the online learning process so far through Zoom and Google Classroom. Interviews were conducted by asking questions related to students' perceptions of online learning according to interview guidelines. A total of 10 questions were asked to 10 students who had been selected to conduct interviews.

The results of observations made by the writer on the online learning process by using the Zoom and Google Classroom, overall based on 10 questions have a score of 13 , with an average score of 1.9 and fall into the category of good, as well as the effectiveness or success rate of theonline learning process of $61.9 \%$. This shows that the online learning process of English lesson by using Zoom and Google Classroom can be said to be quite good. Here are the details of observations about the online learning process by using the Zoom application and Google Classroom in this study, presented in Table 4. 
Purwanti Taman, Sukma Septian Nasution, Tommy Hastomo, Nur Najibah Sukmawati, Laksmy Ady Kusumoriny

Table 4. The results of observations by using Zoom and Google Classroom

\begin{tabular}{|c|c|c|}
\hline No. & \begin{tabular}{|l|} 
Indicator of \\
Observation
\end{tabular} & The Result of Observation (Score) \\
\hline 1. & $\begin{array}{l}\text { Preparation of facilities } \\
\text { in the online learning } \\
\text { process, especially } \\
\text { internet connection. }\end{array}$ & 2 (Good) \\
\hline 2. & $\begin{array}{l}\text { Preparation in using } \\
\text { the Zoom and Google } \\
\text { Classroom. }\end{array}$ & 3 (Very Good) \\
\hline 3. & $\begin{array}{l}\text { Skills in preparing } \\
\text { materials in teaching by } \\
\text { online learning. }\end{array}$ & 2 (Good) \\
\hline 4. & $\begin{array}{l}\text { Delivering the material } \\
\text { of English learning. }\end{array}$ & 2 (Good) \\
\hline 5. & $\begin{array}{l}\text { Role as supervisor and } \\
\text { supervisor of learning } \\
\text { activities. }\end{array}$ & 1 (Poor) \\
\hline 6. & $\begin{array}{l}\text { Interaction between } \\
\text { teacher and students. }\end{array}$ & 1 (Poor) \\
\hline 7. & $\begin{array}{l}\text { English learning } \\
\text { evaluation }\end{array}$ & 2 (Good) \\
\hline & Average Score & 1,9 (Good) \\
\hline & Amount Score & 13 \\
\hline & Percentage (\%) & $61,9 \%$ \\
\hline
\end{tabular}

Based on Table 4., it can be noted that the average score of observation of online learning process by using Zoom and Google Classroom is 1.9 and falls into the category of good. In addition, it is also known that the score of each observation indicator in online learning. The observation indicator with the good score is the first indicator that is "preparation in using the Zoom and Google Classroom", i.e., a score of 3 falls into the good category. This means that teachers have good skills in using Zoom and Google Classroom for online learning. This can be seen from the skill of the teacher in using every feature contained in both applications. The teacher looks professional and not rigid in using both applications to start the learning process well and on time.

Furthermore, the indicators of observation that have the poor score are the fifth and sixth indicators: "role as supervisors and supervisors of activities" and "interaction between teacher and students" with a score of 1 , and fall into the category of poor score. The poor score is due to the interactive less learning process between teacher and students, so that teacher is more active in the learning process. Students in the learning process only focus on paying attention and following the teacher's orders, and the lack of activities 
stimulates students to be active in the learning process. Overall, the online learning process using Zoom and Google Classroom observed from observations is good, and achieved a success rate of $61.9 \%$.

Furthermore, the researcher obtained the data that learning English online is more complicated than face to face because the students have many obstacles for teaching-learning activity, such as poor internet connection, lack of communication, complex cheating prevention, and zoom fatigue. The students did not know the Zoom application before the Corona outbreak, but they are already familiar with Google Classroom. Zoom application is popular for the teaching media because the students are prohibited from conducting face-to-face meetings. The students have difficulty understanding the learning material because the teacher is too focused on explaining theory rather than practice. If the internet connection of the students is having trouble, they will face the problems, such as delay two-way audio-video, and they cannot interact with the teacher and students in real-time. Based on the observation, some students find the instructional practices boring for monotonous activities a synchronous activity like the platforms can offer. It can be seen from the students' low engagement to the teachers' question where teacher called students many times to respond with almost no voluntary response found. Besides the limitation of online learning, the students explain that online learning has some advantages: easy to use and accessible from many devices, paperless, and speed up the assignment process.

\section{DISCUSSION}

The findings of this study are in accordance with the findings of research conducted by Puspaningtiyas and Dewi (2020) that students' perception of online learning is negative. The indicator that is considered the most obstacle is the technical indicator regarding the Internet signal. Students often experience problems related to the internet during online-based learning. In addition, students also give a negative perception of the understanding of the material through online-learning, in which students feel that the assignments are given too much, while the understanding of the material is very lacking, so it is minimum in doing the task. The app that students are most interested in is also Google Classroom and the results of this study. The use of Zoom application is considered reasonable and appropriate in learning because several menus facilitate the learning process and delivery of materials. The students can learn and understand the material taught by the teacher using share screen feature and can have some discussion using the breakout room feature. And for Google Classroom, the students only got the assignment without explaining it from the teacher and have the assignment fatigue (Heggart and Yoo, 2018). 
Purwanti Taman, Sukma Septian Nasution, Tommy Hastomo, Nur Najibah Sukmawati, Laksmy Ady Kusumoriny

There is a negative perception of students towards online learning in this study due to students' many obstacles. Hastomo (2019) revealed that online learning is considered inefficient because students must have various supporting facilities, such as data packages during learning and often network difficulties. Human resources that master technology are also important factors that need to be considered to achieve learning objectives (Ariani, 2018). Following the results of this study, which constraints on the condition of the internet network and the lack of students' ability to use the Zoom application and Google Classroom, students face obstacles, thus causing negative perceptions.

The results also showed that some students prefer face-to-face learning in the classroom, compared to online learning. This is supported by the results of research conducted by Zuriati and Briando (2020), which states that almost $65 \%$ of students have the perception that learning in the classroom face to face is better than learning online. This case is due to the lack of interaction between students and teachers and between students and other learners. Nasution et al. (2015) stated that direct interaction between students and students, or students with teachers should be present in the learning process to improve communication and discussion about teaching and learning activities, which is not effective in the online learning process. Therefore, online learning will not be more effective than face-to-face learning, so students' perception is negative.

Therefore, there are some efforts to improve online education quality on an ongoing basis, among which is the need to improve the advice and infrastructure supporting online learning such as infrastructure, Learning Management System and adequate repositories. In addition, there is also the need to increase the capacity of the teacher who masters technology to support the implementation of online learning, and also the expansion of technology platform support for online learning activities, such as Zoom and Google Classroom continues, as an effort to improve the insights implementation of online learning to face the rapid development of information and communication technology. It is a requirement in fostering the activities of Life Long Learning Capacity (LLC), especially in the digital era (industry 4.0) today, to grow the younger generation that success in achieving civilized and technologically literate people's lives, to prevent the flow of globalization (Briando and Embi, 2020).

\section{CONCLUSION AND SUGGESTION}

Based on the findings in this study, it can be concluded that students' perception of online learning by using Zoom and Google Classroom during the Covid-19 pandemic is negative. It means that students do not like onlinebased learning because it is more complicated than face-to-face learning. 
Following participants' experience, there are many obstacles during online learning, such as difficulty understanding English materials, a boring learning atmosphere, low internet network conditions, and lack of skills in using applications. These problems are giving rise to a poor experience, thus creating negative perceptions in students. This leads to a suggestion for teachers not to stop the instructional practices via virtual platforms but to find out ways of making students have positive perception to its practices by concerning with the reasons stated by the students.

\section{REFERENCES}

Adijaya Adijaya, N. \& Santosa, L. P. (2018). Persepsi Mahasiswa dalam Pembelajaran Online. Wanastra Jurnal, 10(2), 105-110. https://doi.org/2579-3438.

Agung, A. S. N., Surtikanti, M. W., \& Quinones, C. A. (2020). Students' Perception of Online Learning during COVID-19 Pandemic: A Case Study on the English Students of STKIP Pamane Talino. SOSHUM: Jurnal Sosial Dan Humaniora, 10(2), 225-235.

Ariani, D. (2018). Komponen Pengembangan E-Learning. Jurnal Pembelajaran Inovatif. https:/ / doi.org/10.21009/JPI.011.09

Basith, A., Rosmaiyadi, R., Triani, S. N., \& Fitri, F. (2020). Investigation of Online Learning Satisfaction During COVID 19: In Relation to Academic Achievement. Journal of Educational Science and Technology (EST), 1(1).

Briando, B., \& Embi, M. A. (2020). Work Ethic Principles of State Civil Apparatus in The Ministry of Law and Human Rights of The Republic of Indonesia. International Journal 14 of Advanced Science and Technology, 29(7 Special Issue), 2770-2782.

Ellis, R. (2003). Task-based language teaching and learning. Oxford: Oxford University Press.

Fauziati, E. (2010). Teaching English as a foreign language. Surakarta: Era Pustaka.

Hastomo, T. (2019). Schoology Effects on Students' Writing Ability. Lentera: Jurnal Ilmiah Kependidikan, 12(1), 149-154.

Hammi, Z. (2017). Implementasi Google Classroom pada Kelas XI IPA MAN 2 Kudus. Semarang.

Heggart, K. R., \& Yoo, J. (2018). Getting the most from google classroom: A pedagogical framework for tertiary educators. Australian Journal of Teacher Education, 43(3), 140-153. https://doi.org/10.14221/ajte.2018v43n3.9

Krishnapatria, K. (2020). From 'Lockdown'to Letdown: Students' Perception of E-learning amid the COVID-19 Outbreak. ELT in Focus, 3(1), 1-8.

Latif, S. (2016). Learning Engagement in Virtual Environment. International Journal of Computer Application. 148(11). 7-13. 
Purwanti Taman, Sukma Septian Nasution, Tommy Hastomo, Nur Najibah Sukmawati, Laksmy Ady Kusumoriny

Lestiyanawati, R. (2020). The Strategies and Problems Faced by Indonesian Teachers in Conducting e-learning during COVID-19 Outbreak. CLLIENT (Culture, Literature, Linguistics, English Teaching), 2(1), 71-82.

Maskar, S., \& Wulantina, E. (2019). Persepsi Peserta Didik terhadap Metode Blended Learning dengan Google Classroom. Jurnal Inovasi Matematika, 1(2), 110-121. https:// doi.org/10.35438/inomatika.v1i2.156

Moleong, L.J. (2016). Metodologi penelitian kualitatif edisi revisi. Bandung: Remaja Rosdakarya.

Nasution, A. K. P., \& Ahmad, N. Q. (2020). Student Perceptions of Online Learning during the Covid-19 Pandemic. Jurnal As-Salam, 4(2), 195-204. https://doi.org/10.37249/as-salam.v4i2.219

Nasution, S. S., Tryana, T., Sagimin, E. M., \& Gintings, M. F. M. (2021). The Challenges of Using E-Learning Platform amid Covid-19 Outbreak: Voices from the Lecturers.

Onyema, E. M., Ogechukwu, U., \& Anthonia, E. C. D. (2019). Potentials of Mobile Technologies in Enhancing the Effectiveness of Inquiry-based Learning Approach. International Journal of Education (IJE), 2(01).

Puspaningtyas, N.D, Dewi, P.S. (2020). Persepsi Peserta Didik Terhadap Pembelajaran Berbasis Daring. Jurnal Pembelajaran Matematika Inovatif. 3(6): $703-712$.

Rahayu, R. P., \& Wirza, Y. Teachers' Perception of Online Learning during Pandemic Covid-19. Jurnal Penelitian Pendidikan, 20(3).

Rakhmanina, L., Martina, F., Halolo, F. B., Syafryadin, S., \& Noermanzah, N. (2020). Students' Perception on Online English Learning during Covid19 Pandemic Era. Silampari Bisa: Jurnal Penelitian Pendidikan Bahasa Indonesia, Daerah, Dan Asing, 3(2), 428-439.

Santosa, R. (2009). Genre in media discourse. Journal of Bahasa Sastra dan Studi Amerika, 1(1), 1-23.

Saputri, T., Khan, A., \& Kafi, M. (2020). Comparison of Online Learning Effectiveness in the Ele During Covid-19 in Malaysia and Indonesia. PIONEER: Journal of Language And Literature, 12(2), 103-119. doi:10.36841/pioneer.v12i2.700

Sudewi, P. W. Students Perception of E-Learning: A Case Study on the English Students at Sulawesi Barat University. e-Journal of Linguistics, 15(1), 7582.

Sugiyono. (2016). Metode penelitian kuantitatif, kualitatif dan RED. Bandung: Alfabeta.

Sukmadinata, N.S. (2012). Metode penelitian pendidikan. Bandung: Remaja Rosdakarya.

Sukmawati, N. N. (2018). Teacher talk in teaching English for young learners. Jurnal VARIDIKA, 30(1), 62-72. 
Wargadinata, W., Maimunah, I., Eva, D., \& Rofiq, Z. (2020). Student's responses on learning in the early COVID-19 pandemic. Tadris: Journal of Education and Teacher Training, 5(1), 141-153.

Walgito, B. (2010). Pengantar Psikologi umum. Yogyakarta: C.V. Andi.

Zuriati, S., Briando, B. (2020). Persepsi Siswa Terhadap Pembelajaran Online di Masa Pandemi pada Sekolah Menengah Atas Negeri Empat Tanjungpinang. Conference: Webinar dan Call for Papers. 1-14 